\title{
Servant Leader's Characteristics: Implications for Youth Christian Leaders in FS Community
}

\author{
Ivana Krisantana \\ Departemen of Management, Universitas Surabaya, Surabaya \\ e-mail: ivanakrisantana@gmail.co
}

\begin{abstract}
The world knows many types of leadership, one of which is servant leadership pioneered by Greenleaf (1977). According to Spears (2010), servant leadership has 10 main characteristics that make it unique. These characteristics enable a leader to focus on his/her followers and strive to make them grow better, unlike other leadership styles that focus on organizational interests and goals (Rachmawati and Lantu, 2014). This practice of servant leadership started by Jesus Christ continues to be emulated and lived by many figures after Him. Unfortunately, not all people who claim to be Christians (followers of Christ) actually become servant leaders. This study aims to explore whether the main characteristics of servant leadership really emerge in leaders and still relevant to be practiced in church life today. We will focus on exploring servant leadership practices at FS Community, the youth community of GKA Gloria Pacar, using observation, interview, and document analysis. The ten characteristics that discussed in this research are listening, empathy, healing, awareness, persuasion, conceptualization, foresight, stewardship, commitment to the growth of people, and building community. These are not a requirement that all must be prominent in each leader, but rather are the traits of servant leaders. It means, the more these characters are seen in a person, the more he/she has a heart that is willing to serve, and the closer he/she is to the picture of a perfect servant leader. Although perfection is not possible because we are only limited human beings, these ten characters must be a dream to be pursued by leaders who claim themselves as servant leaders.
\end{abstract}

Keywords - Church, Leadership, Servant, Servant Leadership, Spiritualism.

\section{INTRODUCTION}

$\mathrm{R}$ ACHMAWATI and Lantu (2014) said that the world of leadership today began to shift from 'leaders must have the power to organize followers' to 'leaders must be willing to serve them' [1]. The term 'servant leadership' was first introduced by Greenleaf in 1977, although researchers believe the practice of servant leadership was first started by Jesus Christ about 2,000 years ago (Rachmawati and Lantu, 2014) [1]. His example inspired many leaders who lived afterwards to become servant leaders: Mahatma Gandhi, Mother Teresa, Nelson Mandela, and many more (Perdana, 2018; Utomo, 2018; and Yasinta, 2018) [2]-[4]. Unfortunately, not all people who claim to be followers of Christ, or Christians, actually become servant leaders like Jesus. History has found many Christian leaders who committed corruption, collusion, nepotism, bribes, and even sexual harassment (Tindage, 2008; Fadhil, 2019; and Utomo, 2019) [5]. The gap between theory and concept of servant leadership with its practice inspire us to explore this topic. 'What are the main characteristics of servant leadership and whether these characters are really emerge in the lives of
Christian leaders today?' are the main question needed to be discussed deeper.

This study will focus on FS Community, the youth community of GKA Gloria Pacar. GKA Gloria is one of the large and well-known churches in Surabaya, Indonesia, that has been established since 1928 and now has 5 branch churches and 5 future churches. Gloria also established schools and clinics to support its service in this world, especially in Surabaya. The youth community is chosen because youth is the future generation of the church, who determine to which direction this organization will move. As Kailash Satyarthi said,

"The power of youth is the common wealth for the entire world. The faces of young people are the faces of our past, our present and our future. No segment in the society can match with the power, idealism, enthusiasm and courage of the young people" (Satyarthi, 2018) [6].

\section{A. Servant Leadership}

Dobbins and Pettman (1997) said leadership is the ability to motivate people to strive to achieve common goals and to draw extraordinary performance from ordinary people [7] Leaders inspire and motivate others, put meaning and purpose into work, communicate well, and build winning teams (Dobbins and Pettman, 1997) [7]. There are many leadership styles that can be adopted by leaders, for example autocratic leadership, democratic leadership, laissez-faire, transactional leadership, transformational leadership, authentic leadership, charismatic leadership, ethical leadership, spiritual leadership, and servant leadership (Lewin et al., 1939; Bass, 1990; Macik-Frey et al., 2009; Van Dierendonck, 2011; Eva et al., 2019; Huertas-Valdivia et al., 2019) [8]-[13].

Robert Greenleaf was the first to introduce the term servant leadership, although he did not provide a definition of it. In his essay, he (1977) wrote that the great leader is seen as servant first [14]. Further, he said,

"The servant leader is servant first... It begins with the natural feeling that one wants to serve, to serve first. Then conscious choice brings one to aspire to lead... Servant leaders seek to transform their followers to \& quo; grow healthier, wiser, freer, more autonomous, and more likely themselves to become servants" (Greenleaf, 1977) [14].

Sendjaya is the one who give the most complete definition of servant leadership. He (2015) said servant leadership is a holistic approach to leadership that engages both leaders and followers through its (1) service orientation, (2) authenticity focus, (3) relational emphasis, (4) moral courage, (5) spiritual motivation, and (6) transforming influence such that they are both transformed into what they are capable of becoming [15]. 
The $1^{\text {st }}$ International Conference on Business and Engineering Management (IConBEM 2020)

February $1^{\text {st }} 2020$, Institut Teknologi Sepuluh Nopember, Surabaya, Indonesia

\section{B. Jesus Christ, The First Servant Leader}

According to Fry (2003), servant leadership is supported by many religions, such as Islam, Christianity, Judaism, Hinduism, Buddhism, and also philosophies outside of religion, like moral philosophy, yoga siddha, and Taoism [16]. But the concept of servant leadership is most often associated and most closely related to Christianity because Jesus Christ was the first Figure in history who practice servant leadership (Rachmawati and Lantu, 2014) [1]. In one of His teachings, Jesus gave a parable about the good Samaritan who put others first and serve them (Luke 10:2537, NIV) [17]. As a Teacher at that time, Jesus also set an example by washing His disciples' feet (John 13:1-17, NIV) [17]. He even said,

"You call me 'Teacher' and 'Lord', and rightly so, for that is what I am. Now that I, your Lord and Teacher, have washed your feet, you also should wash one another's feet. I have set you an example that you should do as I have done for you" (John 13:13-15, NIV) [17].

The greatest example of service that Jesus gave was to gave His life for men (Philippians 2:6-8, NIV) [17]. He is God who come to serve, not to be served (Matthew 20:28, NIV) [17]. Jesus' teachings and example must be adopted by His followers, whether the world accepts it or not (Dyck and Schroeder, 2005) [18]. According to them (2005), people who take after Jesus will not use their physical power, political, or position to get things from others [18].

\section{Ten Characteristics of a Servant Leader}

Spears (2010) identified a set of ten characteristics of the servant leader [19].

\section{1) Listening}

Leaders need to be reinforced by a deep commitment to listening intently to others. Servant leaders listen receptively to what is being said and unsaid by others, so they can identify the will of a group and help to clarify that will.

\section{2) Empathy}

Servant leaders should try to understand and empathize with others, because people need to be accepted and recognized for their special and unique spirits.

\section{3) Healing}

One of the greatest strengths of servant leadership is the potential to heal one's self and one's relationship to others. Many people have broken spirits and have suffered from a variety of emotional hurts. Although this is a part of being human, servant leaders use this opportunity to help make whole those with whom they come in contact.

\section{4) Awareness}

General awareness, and especially self-awareness, strengthens the servant leader. Awareness helps one in understanding issues involving ethics, power, and values. It lends itself to being able to view most situations from a more integrated and holistic position. At a higher level, awareness enables servant leaders to choose a particular career/job because they understand their purpose/calling (Sendjaya, 2015) [15].

\section{5) Persuasion}

The servant leader seeks to convince others rather than coerce compliance. He/she is making decisions reliance on persuasion, rather than on one's positional authority.

\section{6) Conceptualization}

Servant leaders have the ability to look at a problem or an organization from a conceptualizing perspective. They are called to seek a delicate balance between conceptual thinking and a day-to-day operational approach. This conceptualization ability is closely related to vision, because to be able to serve others, servant leaders need to know what is not known and see what is not seen (Greenleaf, 1977) [14].

\section{7) Foresight}

Foresight is a characteristics that enables the servant leader to understand the lessons from the past, the realities of the present, and the likely consequence of a decision for the future.

\section{8) Stewardship}

Block (1993) defined stewardship as holding something in trust for another [20]. Servant leadership, like stewardship, emphasizes the use of openness and persuasion, rather than control. It choose partnership over patriarchy, delegation and decentralization over centralization (Block, 1993) [20].

\section{9) Commitment to the Growth of People}

Servant leaders are deeply committed to the growth of each and every individual within their organization. They recognize the tremendous responsibility to do everything in their power to nurture the personal and professional growth of employees and colleagues. Sendjaya (2015) acknowledged, leaders need to influence their followers through their skills in public speaking, meetings, social media and other ways [15]. Servant leaders too, but the impartation of a real and significant vision occurs through one-on-one meetings (Sendjaya, 2015) [15].

\section{0) Building Community}

Servant leaders need to create a positive atmosphere that support the growth and development of their followers in organization, so that they can transform for the better (Sendjaya, 2015) [15]. The atmosphere referred to is the space for learning and making mistakes, process of gathering and discussing information together, and time to reflect (Van Dierendonck, 2011) [12].

\section{METHODS}

\section{A. Interview}

Two servant leaders in FS Community who will be interviewed is Natan and Maria, the Youth Pastors of FS Community. Questions asked are about their leadership position in church, the service they do, the obstacles that arise when they serve and how they deal with those, and the way they transform their followers to be better. To obtain a holistic perspective, some of the followers will be interviewed too. Questions asked are about their relationship with these leaders, the service their leaders do, and their desire to become better person and servant leaders because they are inspired by their leaders. These interviews take place at FS Community or other agreed places.

\section{B. Observation}

This method is used to find out exactly how servant leaders practice their leadership style, especially in their interactions with their followers. Observations are made at least on Sunday, when servant leaders and their followers meet at the 
The $1^{\text {st }}$ International Conference on Business and Engineering Management (IConBEM 2020)

February $1^{\text {st }} 2020$, Institut Teknologi Sepuluh Nopember, Surabaya, Indonesia

church. Additional observations can also be made when servant leaders and their followers meet on other days and/or outside the church. Their sermons will also be observed.

\section{Document Analysis}

We collect and analyze FS Community's Standard Operational Procedure (SOP); photos of servant leaders and their followers meeting, including Sunday Services and other events, servant leaders' chit chats; and also their posts on social media.

\section{RESULTS AND DISCUSSION}

\section{A. Serving and Leading}

At the highest level of FS Community, there are Natan and Maria as youth pastors. How they serve will determine how the committees and the other members serve. In addition, the vision and mission of FS Community depend on the pastors who lead. These pastors will define and present the vision and mission to FS Community's committee, because the committee changes every 2 years, while the pastors doesn't.

This role is played more by Natan. In 2017 when he first served as a youth pastor, Natan suggested the committee at that time to start creating a standard operational procedure (SOP). Natan focuses more on the committee, especially the key persons in it, because he considers the committee as the head of the community, who will determine how FS Community moves for 2 years. Natan also leads the care group leaders (CGLs) because of the same principle: they are the leader of each care group (CG), so ensuring they walk the right path is the same as making sure all $C G$ members walk the right path. His focus on leaders did not make Natan ignore other members. He gets along and serves all members, also tries to attend every events held by FS Community. One characteristic of Natan's leadership style is doing a chit chat. He usually invites one or several members to eat or hang out together. In every chit chat, Natan always pays for the food and beverages ordered and said, "Inilah pelayanan saya. Uang yang saya miliki memang saya gunakan untuk ini."

Unlike Natan who focuses on leaders at the top of FS Community, Maria plays a supportive role for her husband. She realizes that an organization does not need many main leaders, but rather need people who support the main leader. Maria helps her Natan in routine work, such as preparing sermons schedules and themes, preparing CG topics, leading fellowships, and so on. When Natan busy, Maria replace his several times. Vice versa. If Natan focuses on equipping the CGLs, Maria, who has a heart for discipleship, becoming a CGL in several CGs herself. Maria is an introvert person, so her approach is more personal than Natan. Before and after Sunday Service, Maria usually approaches and accompanies people who are quiet and alone, in contrast to Natan who is more often seen with activists. Outside the church, Maria often contacted members through chat to simply ask how they are doing. At this community, Maria can be described as a mother who always ready to listen and hug her children. Although the initiative to chit chat comes from Natan who is more extrovert, Maria also attends every chit chat.

\section{B. Program Planning, Implementing, and Monitoring}

Programs in FS Community is planned annually. The Youth Pastors, Chairman, and Deputy of FS Community will discuss and determine together the goal to be achieved in the following year. The agreed goal will be communicated to other committees, so each department can develop programs to achieve the big goal. Youth pastors have a vital role in this planning process, especially when determine the big goal. Natan and Maria usually give considerations from a more holistic perspective, because of their knowledge and experiences. After the big goal is determined, they entrust the details to the committee. Nevertheless, Natan and Maria almost always attend the meetings, help provide direction and input when needed. When there are differences of opinion, they usually mediate and give understanding to both parties. Sometimes they give input which one they think is better option, but it always ends with, "Tapi terserah kalian, mau putusi yang mana. Pilihan yang mana pun, kami pasti dukung."

All implementing programs are always led by one of the committee, like what is stated in FS Community's SOP. Sometimes Natan and Maria ask the committee in charge how are the preparations and what is need to be helped. Program monitoring is generally carried out by the Chairman and Deputy of FS Community through regular plenary meetings. The role of youth pastors in this process is not that big, because they believe the chairman and deputy are able to do this well.

\section{Difficulties and Challenges in Serving and Leading, and How to Overcome Them}

There are some difficulties and challenges faced by servant leaders in FS Community: disharmony within the church, and Chinese church culture. The disharmony within the church occurs especially at the top level of management. There are some pastors in GKA Gloria who jealous of Natan and Maria, because they are placed to serve in youth community. They think leading in FS Community is easier because youth are considered to be matured enough and have the potential to do many things. The next difficulty faced by servant leaders is the church culture. Because GKA Gloria is a Chinese church, there are some bad habit/culture that still occur. For example is seniority, cold atmosphere and passive people.

There are several ways these servant leaders do to overcome these difficulties and challenges. The first and the most important is having a good spirituality. In terms of Christianity, one should have an intimate relation with God. When interviewed Maria said,

"Tuhan itu kasih tahu aku bahwa Dia itu Gembala, seorang Gembala yang punya gereja. Jadi ketika Dia Tuhan yang punya (adalah) Gembala, Dia akan menolong kami ini yang adalah gembala-gembala yang Dia utus ke tempat ini untuk menggembalakan ini semua. Jadi ketika ada masalah, pergumulan, aku selalu inget Tuhan ini Gembala. Jadi ya misale aku kayak bermasalah, misale dengan rekan kerja,

harus memotivasi keluarga, sama menyemangati suami

untuk tetap bertahan, itu aku pasti cari Tuhan. Kayak gitu..."

Their intimate relations with God will enable them to serve and provide the best for the followers, even though at that time the fruits of their ministry have not been seen yet. Another way to overcome these difficulties is to be a solution. Natan and Maria continue to be kind to other pastors, no matter what response they receive. About seniority and the 
The $1^{\text {st }}$ International Conference on Business and Engineering Management (IConBEM 2020)

February $1^{\text {st }} 2020$, Institut Teknologi Sepuluh Nopember, Surabaya, Indonesia

cold atmosphere, these two become the real examples of people who get along with everyone without care about age.

\section{Ten Characteristics of Servant Leadership}

\section{1) Listening}

Natan and Maria did not explicitly say that listening is the main thing they do as leaders. But in her interview, Maria told the condition of her CG which consisted of many people so it was naturally divided into 2 groups: talkative members and quiet members. Maria also shared that she gave different treatments to these groups. She asked more questions and asked quiet members to share their stories, and asked talkative members to learn to listen. This simple act shows that Maria is aware listening is important. It is a discipline that needs to practice continuously, like what Sendjaya (2015) emphasizes [15].

Unlike Maria who's already known as a good listener, Natan is better known as sociable and talkative leaders. However, that does not mean he's not trying to listen to others. At the beginning of 2019 he invited the FS Community's committee to his house. These 20 committees was invited to his house according to their department, so that each meeting there were only about 5-6 people. During those meetings, there was no discussion about programs, but everyone take turn to tell their struggles and problems. Some shared their pasts, problems with family, friends, work, worries about future, and so on. They cried while doing this. That moment became a point where Natan, Maria, and the committee learned to listen to, to understand, and to support one another. This is consistent with Covey's opinion (1991) that listening sincerely can develop the strength of servant leaders and improve relations between a leader and his/her followers [21].

\section{2) Empathy}

Greenleaf (1977) said that servant leaders think problems that occur in the world as personal tasks that must be resolved, so that they care and empathizes with others and can help them become better persons [14]. This definition is in line with the example given by Natan. There was an old woman who is hospitalized several times. Natan always took his time to visit her. One afternoon when she's hospitalized again, Natan went to visit even though he was exhausted after badminton. Natan insisted on accompanying her because there was no one look after her. Finally Natan went home because this woman told so. Shortly afterwards, Natan was told by the hospital that the woman died. Natan, the last person she met with before she died, immediately went back to the hospital. Natan represented the family to do this and that which was needed, followed all the processes until 2 o'clock in the morning, and he was the one who contacted her family. Natan admitted it was the first time he saw how the body was bathed. Not surprisingly, one of this woman's children cried when he shared Natan's deeds at the consolation service. Natan's act is a clear proof that empathy of servant leaders enable them to have a sense of caring, put themselves in the others' positions, and consider a problem as their personal duty (Greenleaf, 1977), so they will do it without being told [14].

There was also a time when a young woman cried alone after being scolded by her friend. When other people ignored her, Maria came to her. She listened to her story, even cried with her as if she herself experienced and felt it. Maria's actions prove Spears's statement (2010) that servant leaders always accept, try to understand, and empathize with others as they are [19].

\section{3) Healing}

Sendjaya (2015) emphasized that servant leaders accept others as who they are, not depending on how their behavior toward leaders [15]. Servant leaders realize that people are not free from mistakes, so they are willing to forgive, forget, and accept others back unconditionally and without judgment (Autry, 2001) [22]. In practice, Natan and Maria who felt that the other pastors were competitive and less supportive, did not do the same thing. In her interview Maria said, "Even kamu nggak suka dengan rekan Hamba Tuhan, kamu itu nggak boleh punya kepahitan dengan dia, nggak boleh marah dan bertengkar dengan sesama Hamba Tuhan."

Having a recovered self and healthy relationships with others, enables servant leaders to help others to recover as well as their relationships. In his interview, Natan told that in Surabaya he and Maria handled several special cases seriously. There's a young man who had an acute addiction to online games. He had dropped out from school and only played from morning to night. His parents even provided 2 Wi-Fi at home, so that when one had a problem, their child can still be connected to the internet using the other Wi-Fi. If not, he will be angry uncontrollably, shouting, even banging himself against the wall. Thanks to Natan and Maria who were willing to be bothered with this case without feeling impatient or protest because they realized that they had the opportunity to help he recovered (Spears, 2010 and Sendjaya, 2015), he slowly changed [15], [19]. Now, he can continue his study again, abroad. Before leaving for Singapore, he told his life testimony at the FS Community Sunday Service.

Another time there was a woman who told her life problems to Maria. The woman ran away from home because of a big fight with her husband. All of her assets were left behind because she used her husband's name. While her husband does not work and has a lot of debt which is bestowed on his wife. While listening to the story, God encouraged Maria to share God's Word with the woman. The woman cried hearing that and thanked Maria. While telling this story in her CG, Maria said,

"Sebelum aku ketemu ibu itu, beberapa waktu yang lalu itu aku dapet ayat Firman Tuhan waktu saat teduh, gitu lho. Aku nggak ngerti ayat itu bicara apa, 'Aku nggak ngalami itu Tuhan', tapi ayat itu itu bicara gitu sama aku. 'Ini pokoke ayat buat kamu', kataNe. Ternyata ayat ini yang tak kasih sama ibu itu gitu lho maksude."

\section{4) Awareness}

Servant leaders are aware that their lives are not made up of random things, but each background, temperament, training, and life experience are woven together to make them the most appropriate person to do a job (Sendjaya, 2015) [15]. Like Maria who is aware of her strengths and uses it to serve others,

"Jadi aku itu bisa tahu orang itu ada masalah atau nggak gitu. Jadi misale aku berdoa di rumah, nah itu bisa ada nama orang yang muncul gitu Nah nanti aku approach dia, dan memang bener dia ada masalah. Sering kayak gitu." 
The $1^{\text {st }}$ International Conference on Business and Engineering Management (IConBEM 2020)

February $1^{\text {st }} 2020$, Institut Teknologi Sepuluh Nopember, Surabaya, Indonesia

Beside prayer, Maria also has a strong memorize. She uses her ability to memorized everyone's name, address, family, even sitting position in church. She knows people who didn't come to Sunday Service, asks them the following week, and even visits them. This finding proves that servant leader's awareness creates interconnection between one's inner self and the world, enables servant leader to understand his/her calling so that he/she can choose a particular career/job (Stamp, 1991; Sendjaya, 2015) [15], [23].

Awareness helps one in understanding issues involving ethics, power, and values, so he/she can has more integrated and holistic view (Spears, 2010) [19]. Maria's awareness about her CG's condition drives her to be a good mediator between the talkative members and quiet members. Her example makes one of her followers notices and tries to emulate Maria's example. In the interview conducted, this followers said, "Karna lihat Ce Maria yang bisa berbaur di $C G$, tiap $C G$ aku jadi berusaha buat ga nge-gap. Jadi aku tahu kalo aku duduknya sama si A atau sama si B, aku pasti ributnya sama mereka. Jadi aku kalo CG misal ada pilihan, aku nggak duduk di deket mereka pasti."

In contrast to his wife, Natan's calling is to serve the key persons in the organization. So he spends more time with the FS Community chairman and deputy than with other members. Natan also decides not to lead a CG like Maria do, but he focuses to equip the existing CGL. At the time of regeneration the committee, Natan always volunteers to approach the chairmen candidates. Specifically, he invites the chairmen candidates to eat together and chat, as well as sharing each other's visions and struggles. His past experience also contributed. In the church where he served before GKA Gloria Pacar, Natan led all the department and commission there, so he focused on top level leaders. These things are done by Natan not because he is picky about certain jobs or people, but because he is aware that leaders are the key to an organization, so ensuring leaders grow enables them to grow others as well. Natan said, "Saya mengibaratkan itu kayak kepala. Kalau kepalanya itu nge-heng, semuanya pasti nge-heng. Kalau kepalanya panas nanti bisa mukul lah, bisa apa. Tapi kalau kepalanya bener, ya bisa jalan semuanya."

\section{5) Persuasion}

A servant leader encourages followers to grow achieving their maximum potential, not by force, but by persuasion (Spears, 2010) [19]. In her CG, Maria usually persuades members to have an intimate relationship with God through reading the Bible, praying, etc. She said, "Ya aku selalu mendorong temen-temen di sini, jangan lupa untuk tetep saat teduh, tetep berdoa, baca Firman, trus tetep bener-bener berpegang teguh sama Firman Tuhan." She also persuades her members to start serving and leading in FS Community. She asserted that "Kita harus ngobrol dulu, harus sharing beban kita supaya orang itu ikut punya hati sama seperti kita." Heart that she referred to is a heart that loves God and His church, which encourages them to serve others. Maria's opinion is in line with Greenleaf (1998) who says that people will follow the servant leader's example voluntarily, because they are successfully persuaded that the path taken by their leader is the right path for them to take [24].

Natan also said the same thing,

"Strategi yang saya pakai itu saya sebut dengan istilah impartasi. Kamu pasti pernah denger istilah amputasi kan ya. Kalo amputasi itu adalah memotong apa yang sudah ndak hidup supaya bagian kita yang masih berfungsi masih bisa baik. Tapi kalau impartasi itu adalah memberi kepada orang bagian tubuhmu yang aktif, sehingga orang itu juga bisa hidup. Nah cara itu saya lakukan secara konkrit adalah setiap kali saya berjumpa dengan orang yang saya rasa punya modal, punya skill, saya akan selalu cerita tentang apa sih passion saya, apa sih kerinduan saya, sehingga dia juga bisa menangkap. Jadi kita berada di sepatu yang sama, kita memakai sepatu yang sama, kita jalan sama-sama."

The success of his persuasion and impartation can be seen from the testimony of the FS Community's Chairman. Although at first he was reluctant to become chairman because he felt inadequate, thanks to Natan, he decided to continue serving as an committee, and even dared to try to run for chairman, so that he could serve others better. He said, "Waktu approach aku jadi calon ketua, dia (Natan) bilang, 'Ko Nat ini butuh kalian. Ko Nat kan orang baru di sini, kalian orang lama.' Padahal awalnya aku gamau lanjut jadi pengurus bahkan. Pinter persuasi Ko Nat ini."

\section{6) Conceptualization}

Servant leaders have the ability to look at a problem or an organization from a conceptualizing perspective (Spears, 2010) [19]. Maria as one of the CGLs in FS Community realize the importance of having a long term view of discipleship. this view enables Maria not to be disappointed when her services have not shown results. She said,

"Keberhasilan pemuridan itu nggak bisa kita lihat dalam waktu singkat, satu sampai tiga tahun, itu nggak bisa. Lima tahun kamu hanya lihat buahnya sedikit saja. Tapi kalau kamu mau lihat buahnya itu nanti 15 tahun. Jadi kalo kita mau lihat pemuridan kita berhasil atau nggak itu kita belum tahu. Itu namanya long life discipleship. Kita harus invest waktu panjang untuk itu."

According to Sendjaya (2015), conceptualization is closely related to having a vision, which is a picture that has not been seen in the eyes of others but can already be seen by leaders [15]. Unfortunately, vision is not yet visible in the lives of the top leaders in the GKA Gloria Pacar. Natan, one of the top leaders, admitted himself that

"Kalau kita cuma mikirin Fong Shien... sederhana aku bilang. Tapi Fong Shien ini bagian daripada gereja secara utuh, sehingga kita mesti cari, mesti menemukan leader yang betul-betul punya visi untuk melihat gereja ini secara besar, nggak bisa secara sempit. Maka dari itu menemukan leader yang punya passion, yang punya visi melihat besar, itu ndak gampang. Nah itu yang sebenarnya aku sedang kerjain."

Natan aware, to be able to survive in the future, this church needs to change. The first step is to have visionary leaders who are able to think long term, not only think about the daily operations of the church. So right now, Natan focuses on preparing the next generation leaders. He knows that people he served in FS Community will occupy important positions in the next few years. He said, "Jadi aku di tahun kedua ini, sampai tahun kelima mungkin, fokus untuk menemukan leader. Create leader. Dampingi, nemenin, memoles supaya mereka jadi leader. Jadi mereka punya pandangan yang global terhadap gereja, pandangan yang baik." One of the followers he prepared said,

"Ko Nat sering bilang kalo kita ini generasi penerus gereja. Meskipun sekarang kita susah, banyak diatur dan 
The $1^{\text {st }}$ International Conference on Business and Engineering Management (IConBEM 2020)

February $1^{\text {st }} 2020$, Institut Teknologi Sepuluh Nopember, Surabaya, Indonesia

dibatesi sama pihak atas, gak bebas ngapa-ngapain, tapi suatu saat kita yang akan duduk di sana. Waktu itu terjadi, kita harus inget supaya gak melakukan hal yang sama."

17) Foresight

Spears (2010) stated that foresight enables the servant leader to understand the lessons from the past, the realities of the present, and the likely consequence of a decision for the future [19]. Natan once told one of his followers' past, namely the Chairman of FS Community,

"Banyak yang memimpin di pemuda, tapi mereka nggak ngerti jadi leader. Sehingga memang harus ditarik, dibina,

baru bisa jadi leader. Misal kayak si YH, dia itu leader.

Hanya di dalam keluarganya dia, dia punya koko, nah kokonya itu yang take care semua company-nya, dia cuma jadi pegawai. Sehingga begitu dia naik jadi leader di pemuda, dia tidak secara otomatis jadi leader, padahal dia punya kualitas leader."

Understanding the past of the people he served and led, enabled Natan to understand how they should be lead and serve today. For example, about the young man he told, Natan encouraged and convinced him that he could become a leader. Natan pushed and persuaded him to dare running for chairman until he finally being elected. During his period as a chairman, this young man continuously consulted with Natan about his personal struggles, his confusion when he had to make decisions, and the difficulties he experienced while leading. At times like those, Natan usually listen to him, help him see the problem from several points of view, accompany him to make a decision, and continue to convince him that the decision he made was good.

In a larger scope, servant leaders are able to understand the past of this church and know exactly what actions must be taken now to create a better future. He realized,

"Di Gloria ini miss link regenerasinya. Sehingga di

kemajelisan itu muter-muter, satu orang bisa sampe 5 periode. Kenapa coba? Karena mereka merasa masih oke, peraturan pun bisa dilanggar, yang buat peraturan mereka

kok. Dari 1 sisi itu tidak baik, itu akan membuat kamu punya rasa kepemilikan terlalu tinggi, sehingga waktu kamu lepasin itu sakit. Kalau Pak Paul Gunadi itu pernah bilang,

'Kita ini perlu belajar seni menggenggam dan seni melepaskan. Jangan genggam terlalu erat tapi jangan terlalu cepat melepaskan.' Artinya lu musti pegang, jangan sampe ini jatuh. Tapi lu ga bisa genggam sampe ini penyok gitu lho."

Natan awares that one of the main problems in GKA Gloria Pacar was the top leaders who continued to rule, not giving the next generation the opportunity to take control. They should have used their better leadership experiences to train and become mentors for the next generation, rather than using those as reasons for them to continue ruling. In fact, if we think further, this condition gave bad effect not only for the juniors who don't stand a chance to develop their service and leadership skills, but also for the seniors who are individualistic and cannot learn to trust others. Natan's awareness prevented him from making the same mistakes in FS Community. Even though FS Community has an option to nominate seniors to become committees again, Natan personally doesn't agree, because the regeneration will fail again.

Maria understood that people in this community are not used to being open about themselves. She realized that a person cannot move forward without acknowledging and releasing the burden of the past and a community cannot be a place to grow if there is no openness, acceptance, and trust in it. So she broke these old culture and created a new one: an openness culture. She said,

"Bersyukurnya dari yang dulu (CG) sistemnya cuma kayak pemahaman Alkitab, trus ngisi pertanyaan, kita sekarang sudah jauh berubah ke arah sharing kehidupan.

Jadi sekarang kita lebih saling mengenal temen kita di dalam 1 grup dan kita bisa saling sharing satu dengan yang lain. Keberhasilan menurutku."

Apart from being open, Natan and Maria find that the most appropriate way to serve in FS Community is by become friends. As Maria said, "Pemimpin itu harus orang yang bisa jadi sahabat buat anggota. Sedih, seneng, susah, tidur samasama, menderita sama-sama, tertawa sama-sama. Itu yang anggota butuhkan. Bukan pemimpin yang 'Kamu harus gini ya, ini pokoknya begini ya." Natan also gave a similar statement,

“Apa yang dibutuhkan Fong Shien saat ini, siapa pun dia, di level leader, baik pembina, sebagai hamba Tuhan, atau pengurus, kalau mereka nggak bisa jadi sahabat, saya bilang... wahh, komunitas ini nggak akan berkembang. Gereja ini banyak sistem yang hirarki. Tapi saya lebih melihat bahwa Tuhan itu tidak menyusun itu sedemikian rupa sehingga ketua majelis itu dipandang lebih rohani dibanding aktivis. Ngerti maksud saya ya... Tuhan nggak pernah ngajarin begitu. Bahkan Tuhan berkali-kali ngomong Dia itu adalah sahabat orang-orang berdosa. Dia itu temennya orang berdosa. Nah saya melihat Tuhan itu memang Kristus itu jadi model Leader yang ideal dan sempurna. Dia mencerminkan kepemimpinan menghamba. Dia menyatakan persahabatan dengan orang-orang yang dibenci, bahkan yang dipandang tidak layak untuk diajak bersahabat."

Jesus, who is God, willingly came down to earth to serve (Matthew 20:28, NIV) [17]. He had a meal with the tax collectors who's rejected by the community at that time, he talked to a Samaritan woman who's the Jew didn't like, and also washed the feet of His disciples (Matthew 9:10; John 4: 5-27; John 13: 4-5, NIV) [17]. In John 15:13 (NIV) Jesus said, 'Greater love has no one than this: to lay down one's life for one's friends' [17]. Not only words, Jesus truly gave His life for friends He served (Philippians 2: 6-8, NIV) [17]. The example He sets is what drives Natan and Maria to become friends and serve people in FS Community.

How to actualize this? Natan explained it clearly,

"Kenapa saya ngomong di media sosial, chit chat, dan sebagainya? Karena itu menjadi sebuah cara saya untuk bersahabat dengan kalian. Kenapa saya ajak ngobrol, saya

ketemu. Ada banyak yang saya ndak posting karena memang kasus tertentu, tapi yang saya posting itu overall ya saya seneng ketemu, ngobrol. Bahkan itu jadi pola untuk sebagian orang. Bahkan itu jadi KPI di tahun ini. Kenapa? Karena mereka melihat bahwa it works."

\section{8) Stewardship}

Block (1993) said that servant leaders act as stewards, someone who can holding something in trust for another [21]. Members truly believe that Natan and Maria can be trusted to help them grow for the better. One young woman said,

"Kedatangan Ko Nat dan Ce Mar ke Fong Shien ini kayak ngasih masa depan yang baru ke komunitas yang 
The $1^{\text {st }}$ International Conference on Business and Engineering Management (IConBEM 2020)

February $1^{\text {st }} 2020$, Institut Teknologi Sepuluh Nopember, Surabaya, Indonesia

selama ini menurutku ga punya masa depan. Bukan karna pemikiran-pemikiran atau konsep-konsep mereka yang spektakuler, tapi lebih karna mereka ngerangkul kita, nemuin potensi terpendam kita, dan meyakinkan kita kalo kita ini bisa."

Although being a steward will make servant leader busier, Natan doesn't feel disturbed. Instead he feels grateful if there are members who actively seek and trust him, "Saya bersyukur karna dia sangat aktif sehingga apapun yang terjadi dia itu cari saya mulai dari level gereja sampai kehidupan sehari-hari." As a leader who wants to serve his members as much as possible, Natan doesn't only care about members' spiritual/church lives. He cares about their entire lives. This is consistent with the member's interview, "Misale aku ada pergumulan apa, aku langsung kontak Ko Natan se."

Servant leadership, like stewardship, emphasizes the use of openness and persuasion, rather than control (Spears, 2010) [19]. It choose partnership over patriarchy, delegation and decentralization over centralization (Block, 1993) [21]. Natan acknowledged that he focused more on the big vision of FS Community. Next, he discussed with the core leaders about what actions must be taken to achieve the goal. This is done not to lighten his burden, but rather because he wants to provide opportunities and encourage members to learn to develop themselves and contribute to the organization.

\section{9) Commitment to the Growth of People}

Servant leaders are deeply committed to the growth of each and every individual within their organization (Spears, 2010) [19]. This commitment enables servant leaders to survive in whatever difficulties they face. Natan once said,

"Pelayanan di sini itu... up and down sih rasanya. Up

and down. Saya pernah suatu kali itu saya sangat down.

Nggak ada yang tahu. Tapi even down, saya tetep berusaha tenaga saya $110 \%$ untuk kalian. Hati saya itu akan selalu tercurah untuk kalian, meskipun saya sedang down."

Although serving and leading in this church is not easy an almost made Natan gave up, he still tries to do the best for his followers. He said,

"Saya punya prinsip dari dulu itu, kalau pelayanan prinsip saya hanya 2: harus sampe habis, harus sampe mati. Itu prinsip saya, sudah ndak bisa ditawar-tawar. Sampe mati dalam pengertian... betul-betul hidupmu itu kamu beri ke orang lain, sama seperti Kristus yang Dia sampe mati di atas kayu salib. Sampe habis dalam pengertian kayak kain yang diperes sampe kesed, betul-betul habis."

Servant leaders, including Natan, realized that leaders need public speaking skill, but the real impartation happens through one-on-one meetings (Sendjaya, 2015) [15]. So Natan gives special treatment to some people who he thinks can grow more in the future. He said,

"Semua orang pasti akan kebagian chit chat, karena saya punya prinsip bersahabat sebanyak-banyaknya. Tapi sebagian kecil yang akan dapat treatment khusus. Karena, ya you bayangin aja, murid Yesus tidak banyak, cuma 12, itu pun 1 gagal, ya kan. Jadi memang saya mencoba untuk menciptakan suasana yang seperti Yesus lakukan. Saya memilih orang-orang tertentu, saya mendekati orang-orang tertentu, saya impartasi passion saya pada orang-orang tertentu yang saya lihat itu bisa punya kapabilitas ke sana."

\section{0) Building Community}

Servant leaders need to create a positive atmosphere that support the growth and development of their followers in organization, so that they can transform for the better (Sendjaya, 2015) [15]. The atmosphere referred to is the space for learning and making mistakes, process of gathering and discussing information together, and time to reflect (Van Dierendonck, 2011) [12]. Van Dierendonck (2011) said that to start a learning space, leaders need to set examples by acknowledging their weaknesses first [12]. This has been done by Natan and Maria. Because they did not hesitate to admit their mistakes, the members felt safe in developing themselves in this community.

\section{CONCLUSION}

The servant leadership concept that was initiated by Greenleaf (1977) said that a good leader is a servant first [14]. His desire to serve others encouraged him to take responsibility as a leader in order to serve others more optimally (Greenleaf, 1977) [14]. In fact, the practice of servant leadership in FS Community is not like that. Someone is chosen as a leader not always because people see evidence of his/her service. An example is Natan and Maria who were appointed to become FS Community's youth pastors from the start, before the members knew them, even before they served. The difference between concepts and practices makes leaders need to do something to show their leadership style. The servant leadership characteristics must be truly lived by them, so that members can realize their differences with other leaders in general.

Like organizations and churches in general, FS Community has a variety of programs and events that are held. The process of planning, implementing, and monitoring these programs is not much different from what happens in other organizations. It is the leadership style that gives a different color. The servant leadership characteristics proposed by Spears (2010) are proven to be supported by these leaders, although their form varies. Furthermore, every church must have its own situation, condition, and culture. These certainly influence the practice of servant leadership. The servant leader must have a good spirituality, an intimate relationship with God, and a willingness to be a solution for the problems. The characteristics of their servant leadership must be truly visible to counter the negative culture and build a new positive one.

The ten characters examined in detail in this study are listening, empathy, healing, awareness, persuasion, conceptualization, foresight, stewardship, commitment to the growth of people, and building community. These characters are not a requirement that all must be prominent in each servant leader, but rather are the traits of servant leaders. This means that the more these characters are seen in a person, the more he/she has a heart that is willing to serve, and the closer he/she is to the picture of a perfect servant leader. Even though perfection as a servant leader is impossible, these ten characters must always be a dream to be pursued by leaders who claim themselves as servant leaders.

This study is not perfect and has limitations. Talking about leadership styles is a gray and subjective topic. We cannot say that servant leadership is the best style, but only better than other styles in some ways. In addition, servant leadership 
The $1^{\text {st }}$ International Conference on Business and Engineering Management (IConBEM 2020)

February $1^{\text {st }} 2020$, Institut Teknologi Sepuluh Nopember, Surabaya, Indonesia

discussed in this study refers to the opinion of Spears (2010) which suggests 10 main characteristics of servant leadership. Later, these characteristics can increase, decrease, even change. This research is also limited in terms of research objects, because it only focuses on observing the practice of servant leadership in the youth community of a church. Also, the results of this study cannot be generally recognized because the research object is small. Also, there were only 2 servant leaders interviewed.

The future study can compare the practice of several different leadership styles, not just focusing on one leadership style. Thus we can get an idea of when certain leadership styles are used. Characteristics of servant leadership that will be discussed can also be developed, not only follow Spears'. In addition, the number of interviewee can be increased, to give more diverse perspective. To better understand the practice of servant leadership, this research can be carried out in other churches, even other non-profit organizations. The results of these studies can be used as a comparison and complementary to the topic of servant leadership. We can also observe whether there are differences in the practice of servant leadership in non-profit organizations and profit companies. Further researches are needed to continue developing servant leadership concepts and practices.

\section{ACKNOWLEDGMENTS}

I would like to express my gratitude to Mr. Bonnie for his patient guidance and useful critiques for this research work. My grateful thanks are also extended to Mr. Natan and Mrs. Maria for their help in collecting the research data. I would also like to thank the staffs and members of GKA Gloria Pacar and FS Community for enabling me to use these organization as research objects.

\section{REFERENCES}

[1] A. W. Rachmawati and D. C. Lantu, "Servant leadership theory development \& measurement," in The 5th Indonesia International Conference on Innovation, Entrepreneurship, and Small Business (IICIES 2013), 2014, pp. 387-393, doi: $10.1016 /$ j.sbspro.2014.02.445.

[2] A. V. Perdana, "Biografi Tokoh Dunia: Martin Luther King Jr, Tokoh Persamaan Hak Sipil,” KOMPAS.com, 2018.

[3] A. P. Utomo, "Biografi Tokoh Dunia: Bunda Teresa, Abdikan Diri Bantu Kaum Miskin," KOMPAS.com, 2018.

[4] V. Yasinta, "Biografi Tokoh Dunia: Nelson Mandela, Berjuang Memberontak Apartheid," KOMPAS.com, 2018.

[5] R. Tindage and R. M. P. Hutabarat, Gereja dan Penegakan HAM. Yogyakarta, Indonesia: Kanisius, 2008.

[6] C. O. Oguta, The Invisible Challenges and Prospects for Africa: The Misdiagnosis of Africa. Bloomington, USA: Authorhouse, 2018.

[7] R. Dobbins and B. O. Pettman, "Self-development: the nine basic skills for business success," J. Manag. Dev., vol. 16, no. 8, pp. 521667, 1997, doi: doi.org/10.1108/02621719710174011.

[8] K. Lewin, R. Lippitt, and R. K. White, "Patterns of Aggressive Behavior in Experimentally Created 'Social Climates," Bull. Soc. Psychol. Study Soc. Issues, vol. 10, no. 2, pp. 269-299, 1939.

[9] B. M. Bass, "From transactional to transformational leadership: Learning to share the vision," Organ. Dyn., vol. 19, no. 3, pp. 19-31, 1990, doi: doi.org/10.1016/0090-2616(90)90061-S.

[10] M. Macik-Frey, J. C. Quick, and C. L. Cooper, “Authentic leadership as a pathway to positive health," J. Organ. Behav., vol. 30, no. 3, 2009, doi: doi.org/10.1002/job.561.

[11] D. van Dierendonck, "Servant Leadership: A Review and Synthesis," J. Manage., vol. 37, no. 4, pp. 1228-1261, 2011, doi: $10.1177 / 0149206310380462$.

[12] N. Evaa, M. Robin, S. Sendjaya, D. van Dierendonck, and R. C. Liden,
"Servant Leadership: A systematic review and call for future research," Leadersh. Q., vol. 30, no. 1, pp. 111-132, 2019, doi: doi.org/10.1016/j.leaqua.2018.07.004

[13] I. Huertas-Valdivia, A. R. Gallego-Burin, and F. J. LIorens-Montes, "Effects of different leadership styles on hospitality workers," Tour. Manag., vol. 71, pp. 402-420, 2019, doi: https://doi.org/10.1016/j.tourman.2018.10.027.

[14] R. K. Greenleaf, Servant Leadership: A Journey Into the Nature of Legitimate Power and Greatness. New York: Paulist Press, 1977.

[15] S. Sendjaya, Personal and Organizational Excellence through Servant Leadership: Learning to Serve, Serving to Lead, Leading to Transform (Management for Professionals), 2015th Edi. Switzerland: Springer, 2015.

[16] L. W. Fry, "Toward a theory of spiritual leadership," Leadersh. Q., vol. 14, no. 6, pp. 693-727, 2003, doi: doi.org/10.1016/j.leaqua.2003.09.001.

[17] Biblica, "Bible New International Version (NIV)." Biblica, New York, 2015, [Online]. Available: https://www.biblegateway.com/versions/New-International-VersionNIV-Bible/.

[18] B. Dyck and D. Schroeder, "Management, Theology and Moral Points of View: Towards an Alternative to the Conventional MaterialistIndividualist Ideal-Type of Management," J. Manag. Stud., vol. 42, no. 4, pp. 705-735, 2005, doi: 10.1111/j.1467-6486.2005.00516.x.

[19] L. C. Spears, "Character and Servant Leadership: Ten Characteristics of Effective, Caring Leaders," J. Virtues Leadersh., vol. 1, no. 1, pp. 25-30, 2010, [Online]. Available: https://www.regent.edu/acad/global/publications/jvl/vol1_iss1/home. htm.

[20] P. Block, Stewardship: Choosing Service Over Self-Interest, Unstated. San Francisco, California: Berrett-Koehler Publishers, 1993.

[21] S. R. Covey, Principle-Centered Leadership. New York: Summit Books, 1991.

[22] J. A. Autry, The Servant Leader: How to Build a Creative Team, Develop Great Morale, and Improve Bottom-line Performance. Roseville, California: Prima Pub., 2001.

[23] K. Skamp, "Spirituality and Environmental Education," Aust. J. Environ. Educ., vol. 7, pp. 79-86, 1991, [Online]. Available: https://www.jstor.org/stable/44656077.

[24] R. K. Greenleaf, L. C. Spears, P. B. Vaill, and J. P. Shannon, The power of servant-leadership. San Francisco, California: BerrettKoehler Publishers, 1998. 